\title{
Visually Complex Objects, Ontology of Space and Political Dynamics
}

\author{
Peter S. Wells
}

Humans have been producing 'art' for at least 75,000 years. But the word 'art' is problematic when applied to archaeology. This paper explores the use of the concept of 'visually complex object' to designate a very specific kind of what is generally known as 'art'. I argue for the application of this concept to the analysis of both the design of objects and their arrangement in cultural spaces, to gain new perspectives on social and political change in a prehistoric complex society. The focus here is on visually enchanting objects and changes in the ways that such objects were used and arranged in relation to larger changes in cultural circumstances. I contrast two visual orders in Iron Age Europe-the mid final millennium $B C$, when the visual order of 'princely graves' and the eye-fixing qualities of objects focused attention on the persons of individuals competing for leadership positions; and the second and final centuries $B C$, when a new visual order emerged to focus attention on large, publicly deployed objects that directed attention in open spaces to create collective experiences. The principles developed from these examples from late prehistoric Europe can be applied to changes in other complex societies worldwide.

\section{Visual complexity and 'art'}

The word 'art' is problematic as well as ambiguous when applied to the prehistoric past, or, it could be argued, to any context, even today. People mean so many different things by the word 'art', and in prehistoric contexts, in which intention is so difficult to arrive at, the word is especially problematic. The words 'visual complexity' have a special meaning as I apply them here. Drawing on concepts developed by Gibson (1979) and Gell (1992; 1998), I designate an object as 'visually complex' if it bears clearly delineated texture; has sharply defined edges or frames; is shiny or colourful; and includes images, especially faces of humans, animals, or other beings (for discussion, see Wells 2008, 52). According to this definition, a plainly decorated object is not visually complex-it must have some or all of these special physical features. As I argue in this paper, this concept of visual complexity can be usefully applied to understanding the ways that people have used material culture to express meanings, and how those uses change in the course of larger cultural changes.

\section{Principles of visual order}

As many scholars in different disciplines have shown, how we see depends a great deal on both what we expect to see and our experience seeing (Wells 2012, 18-33). Research in psychology and in neuroscience has shown that some aspects of vision are universal among humans, based on the physiology of eyes and brains (e.g. Gibson 1979; Gregory 1998; Livingstone 2002; Wilson 2002), while other aspects are highly influenced by culture, such that people in different cultural contexts see differently (e.g. De Bolla 2003; Forge 1970; Goldhill 1996; Weismantel 2013, 24, 28; Zedeño $2013,117,119)$. Ways of seeing are closely tied to social and political dynamics of society.

In this paper I explore this concept of visual order in prehistoric complex societies of Iron Age temperate Europe. By 'visual order' I mean the fundamental 
principles by which people in a society use visual devices such as complexity and spatial arrangement to communicate information and feelings. Visual order, as I use the concept here, is closely linked to the word 'style' as that word is employed to mean the way that members of a group (a family, a community, a society) do things-the (usually implicit) rules or codes that govern how a society or a community does things, such as designing special objects and arranging objects in graves and other significant contexts (for discussion of 'style' in this sense, see Knight 2013, 22-4; Shapiro 1963). I suggest that the quality of the data from the context explored in this paper provides the opportunity to make a special contribution to theoretical debates about vision and ontology. I compare the visual order at two different times and in different political circumstances, in the fifth century $\mathrm{BC}$ and in the second century вс. The changes in the character of visual complexity and how it was applied in the material culture are closely tied to changes in social and political dynamics.

\section{Ontologies and visualities in different worlds}

At the outset we need to remind ourselves that we cannot judge complex objects from prehistoric times primarily by how we respond to them, although we must take our responses into consideration. We live in a world very different from that of prehistoric peoples, and indeed from that of our immediate forebears (Lowenthal 1985), and we need to take account of the differences if we are to hope to arrive at a better understanding (Brück 1999). In other words, we need to consider the character of ontologies of societies different from our own twenty-first century perspective on the world and how it works. In 1919, Max Weber wrote of the 'disenchantment' (Entzauberung) of the world with the Enlightenment. As Morris Berman (1981) explains in modern terms, in traditional Europe before the Enlightenment, most people believed that they lived within an animate and 'magical' nature, and that animals, trees, rocks and other natural objects had powers that could potentially affect them (see also, from different disciplinary perspectives, Buchanan \& Skousen 2015; Gilchrist 2012; Groleau 2009; Macfarlane 2015, 24-5; Wilson 2000).

\section{Life histories}

In striving to understand how people responded to the complex objects with which they came into contact, whether directly, by wearing or holding them, or indirectly, by seeing them manipulated by others, we must consider how, where, by whom and under what circumstances they were produced (Kopytoff 1986). At least before the development of the city-like oppida in temperate Europe during the second and final centuries BC, most objects in use and in circulation were made by craftspeople in small communities (Wells 1996). People probably knew who made most of the objects that they used, and had personal relationships with them, and they were probably aware of where the raw materials came from, how they were processed and how the complex objects were finished. All of these stages in the production process were important for how the finished objects were regardedfor the effects they had on people.

In the examples discussed below from the fifthfourth and second-first centuries $\mathrm{BC}$, the principal materials of concern to us (because most of the complex objects were made of them) are bronze, gold and iron. Each of these metals had special properties and each was acquired from a different kind of source (on the importance of materials for perception of finished products, see Helms 2012; Ingold 2012). Copper and tin were procured mainly through mining in hard rock, gold was panned from streams, iron was produced by smelting surface deposits. The procuring of all of these metals required interacting with and extracting from the earth and the application of fire for smelting, casting and forging. These transformations of materials surely contributed to people's beliefs about the efficacy of the metal products that were fashioned into visually complex objects such as those discussed below.

\section{The Late Iron Age in temperate Europe}

I examine here complex objects during two different periods, first during the late fifth and early fourth centuries $\mathrm{BC}$, second during the late second and first centuries BC. This approach will show, by way of contrast, different visual characteristics of complex objects in the two different contexts, different associations and spatial arrangements and different links to the social and political dynamics of the two periods.

In temperate Europe the term Iron Age designates the time from about $800 \mathrm{BC}$ to the time of the Roman conquests in the final century $\mathrm{BC}$ and the first century AD. In the first two centuries of the Iron Age, the cultural landscape is characterized by small settlements, usually with no more than 100 people; a fully developed agricultural economy; manufacturing in a wide variety of materials, including pottery, bronze and iron; and burial practices that reflect growing social differentiation through different degrees of elaboration in burial structures and different quantities and qualities of grave goods buried with the dead. In the 
latter part of the Early Iron Age, roughly $600-450$ вс, central places of regional importance emerged, and with these a tradition of burying some individuals in lavishly outfitted graves under large mounds of earth.

During the fifth century $\mathrm{BC}$, major changes took place throughout temperate Europe that included the decline and abandonment of most of the central places and a radical change in design or visual order. This new visual order that developed during the fifth century ВС is commonly known as 'early Celtic art'. It is best represented on personal ornaments, bronze vessels and bronze and iron weapons in richly outfitted burials of this early phase of the Late Iron Age, known as La Tène A (named after a site in Switzerland). Early Celtic art has been the subject of numerous studies over the past century (e.g. Jacobsthal 1944; Megaw \& Megaw 2001).

The final phase of the Iron Age in temperate Europe (150 BC to the Roman conquests) is characterized by the construction of large, arguably urban settlements known as oppida, mass production of iron tools and of pottery, and the establishment of large open-air sites for the performance of rituals. Design style in this phase of the Iron Age was very different from that of the fifth and fourth centuries $\mathrm{BC}$, as will be seen below.

\section{Late fifth-early fourth centuries BC: Early La Tène}

In the first period, the great majority of visually complex objects have been recovered from graves. From the fifth and fourth centuries BC, we have a huge number of excavated and published burials from all across temperate Europe. A small proportion of them are richly outfitted with visually complex personal ornaments, lavish bronze and ceramic feasting vessels and ornate weapons. Since the late 1800s, these have been designated Fürstengräber, 'princely burials'. The total number of such graves known in temperate Europe from these centuries is in the hundreds, a substantial number, but only a tiny proportion of all known graves of the period (see Beilharz et al. 2012).

Such graves are vital sources of information about the societies of which they were parts. As I have argued elsewhere (Wells 2012, 134-7), arranged graves can be understood as diagrams expressing the visual principles of a society and the social and political concerns of the time, as well as the relationship between the buried individuals and the communities to which they belonged. Most of the richly outfitted graves, such as the two examples below, include in their chambers considerable open space, what Gibson (1977) calls an affordance-spaces that appear to be empty, but that afford possibilities of action and meaning. The arranging of objects in a grave at the time of the funerary ceremony was a key performance in the experience of the community to which the deceased belonged (Wells 2012, chapter 9). When numerous complex objects were arranged in the space of the grave, the placing of them in specific locations and in a special order was a performance that enacted the values, beliefs and traditions of the group. To the archaeologist, the arrangement of objects in a grave is static; but to the participants, including witnesses, in the ceremony, the process was dynamic and powerfully meaningful (see, for example, Ibn Fadlan's description of the performance of a Viking funeral and burial in Jones 1984, 425-30).

\section{Glauberg 1}

The objects: Grave 1 at the Glauberg in Hesse, Germany, contained the remains of an adult male (Fig. 1). The complex bronze fibula from this grave is immediately fascinating (Fig. 2). It has all of the features of Early La Tène eye-catching ornament. It consists of a creature that looks something like a dog, or perhaps a horse, with a long neck and head with huge bulbous nose and protruding eyes, facing backwards in a way that would be impossible for an actual mammal. On the back is a human head, also with large nose and protuding eyes. On an openwork plaque attached to the spring are two more creatures, each facing outward, perhaps stylized horses. Much of the object is covered with very fine linear ornament and beading. It has all the hallmarks of an object designed to catch and hold attention, with the ambiguous and enchanting creatures, the emphasis on faces and eyes and the rich texturing of surfaces (Gell 1998; Gibson 1979).

For Glauberg grave 1, we have detailed information about both relationships with other objects in the grave and the spatial arrangement of objects in the burial. The grave was excavated and recorded in 1994-1995 (Baitinger \& Pinsker 2002; Frey \& Herrmann 1997;). Other objects in the grave that share patterns of ornament with the fibula described above include a bronze and iron belt hook (Fig. 3), a bronze jug with figural ornament on the rim, two bird-head fibulae, a sword with scabbard and a gold neckring (see plan, Fig. 4). The belt hook shows an especially close visual relationship to the fibula, with its stylized animal head, human-like head with bulging eyes, incised linear patterning and beading. All of these objects were placed in the grave as the funerary ceremony was performed. They all relate to one another in that they were arranged at the same time on the occasion of the burial. Each object would have less significance by itself, but together they form a coherent set, much like objects in a bundle or a cache. This set consists of three sub-sets, interrelated by their decoration, communicating three major themes in 


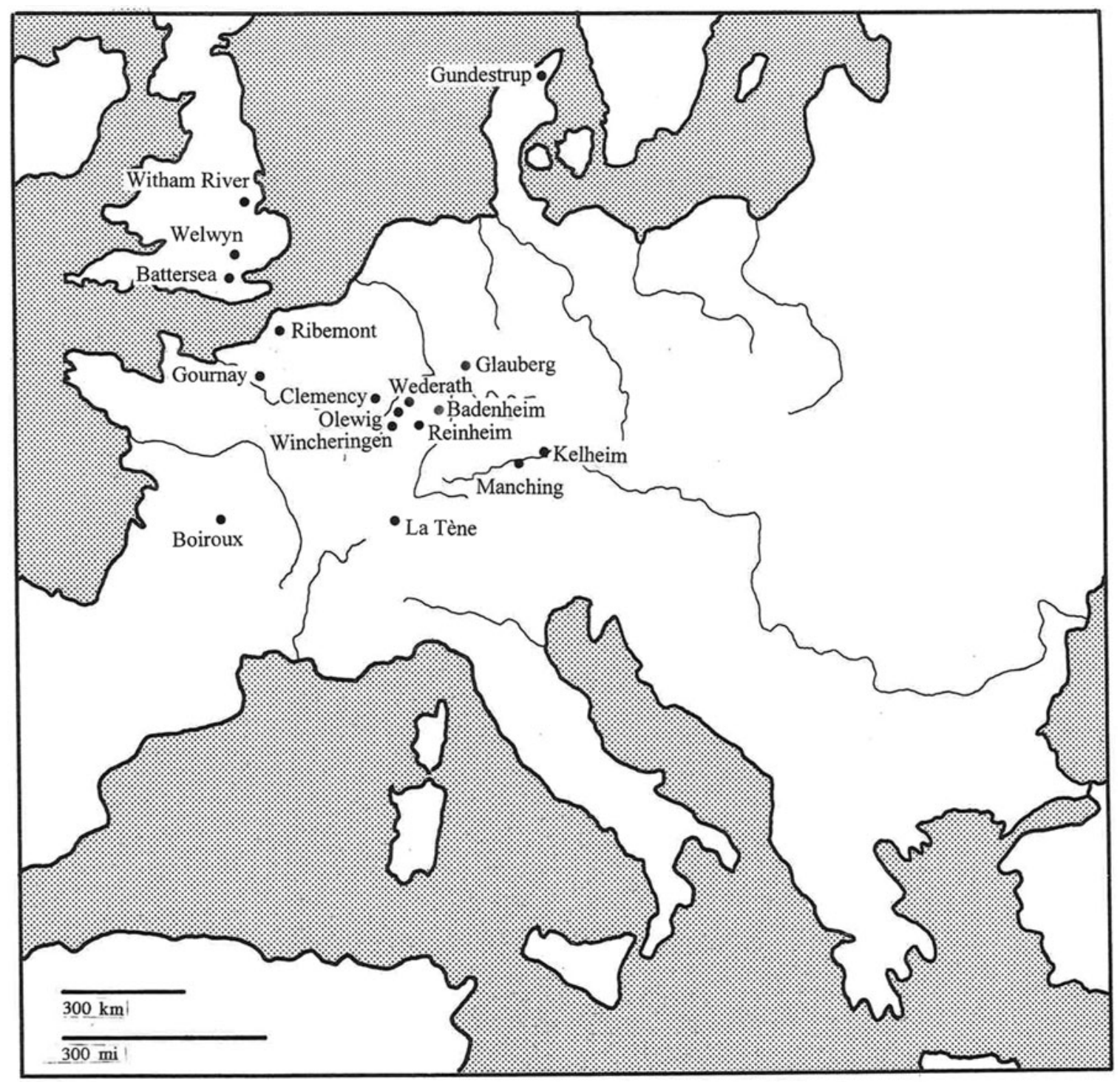

Figure 1. Sites mentioned in the text. (Map: P.S. Wells.)

fifth-century вс Europe-personal expression (fibulae, belt hook, neckring), feasting (jug) and weaponry (sword with scabbard, lances, shield, bow and quiver). These are three themes repeatedly expressed in wealthier burials in Iron Age Europe. If any one of these three were absent, the meaning of the grave would be completely different. These objects can be said to act together to express this particular meaning with respect to the person buried here and the community to which he belonged (Zedeño 2013, 122).

The grave space: From the arrangement of the objects in the grave we can learn fundamental principles of visuality in this context (Fig. 4). The floor of the grave, which measured $3 \times 2.1 \mathrm{~m}$, was prepared in such a way as to leave considerable open space on both sides of the body, as well as above the head and below the feet-an affordance.

We can think of the whole grave as a bundle in the sense described by Zedeño (2008; 2009). It contains three sub-bundles, situated in three different places on the floor of the grave: 1) body with personal ornaments and close-quarter weapons (sword and shield); 2) bronze jug, special fibula, two more fibulae; 3 ) weapons used at a distance-three lances, bow, quiver.

The grave was arranged according to visual principles of the period, which in turn were linked closely to performances. One performance was the man as an active member of his community, accoutred in gold and bronze ornaments that conveyed visual information about his status. Another 


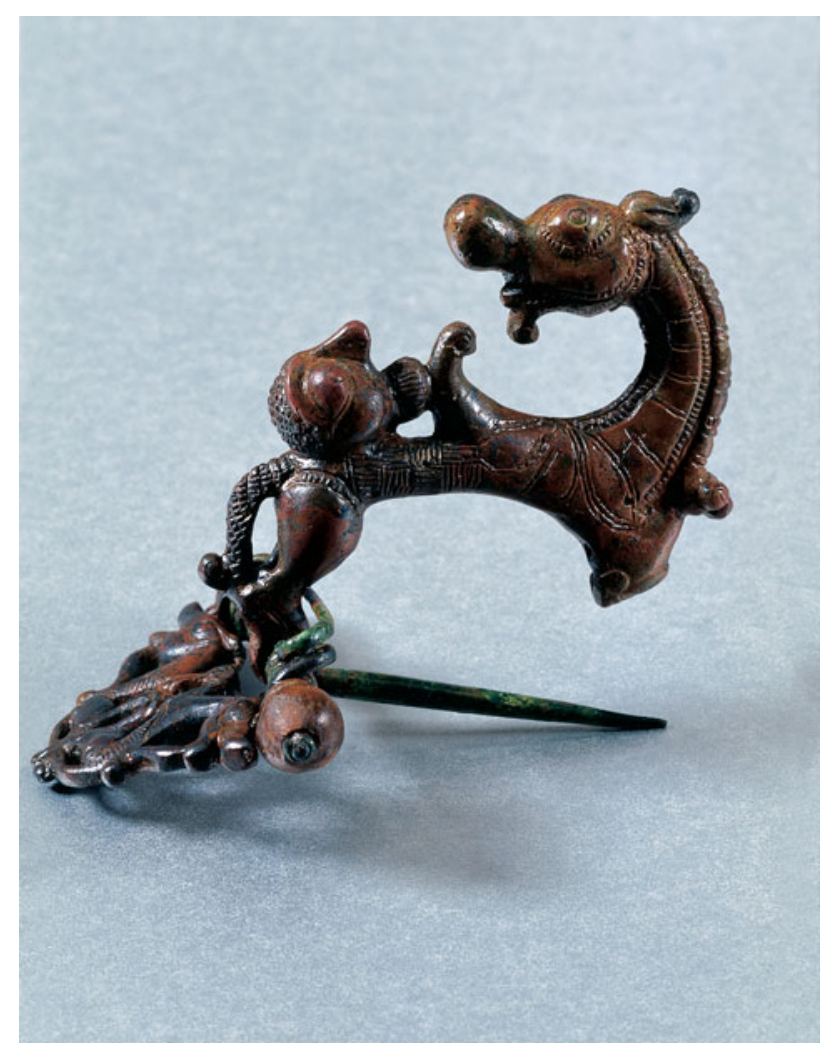

Figure 2. Fibula from Glauberg grave 1. Bronze, iron and coral. Length $6.4 \mathrm{~cm}$. (Photograph: U. Seitz-Gray, Keltenwelt am Glauberg.)

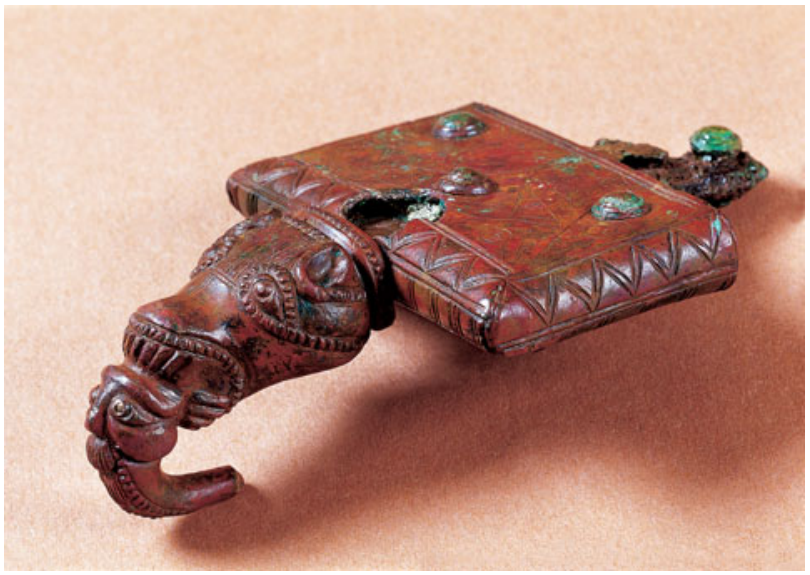

Figure 3. Belt hook from Glauberg grave 1. Bronze. Length $8.0 \mathrm{~cm}$. (Photograph: U. Seitz-Gray, Keltenwelt am Glauberg.)

performance was in his role as host-server of what was probably a special beverage (wine?) contained in the ornate jug in the southeast corner of the grave space. Third was his performance as a warrior or defender of his community (whether or not he ever actually served in these roles), communicated by the

\section{Glauberg 1}

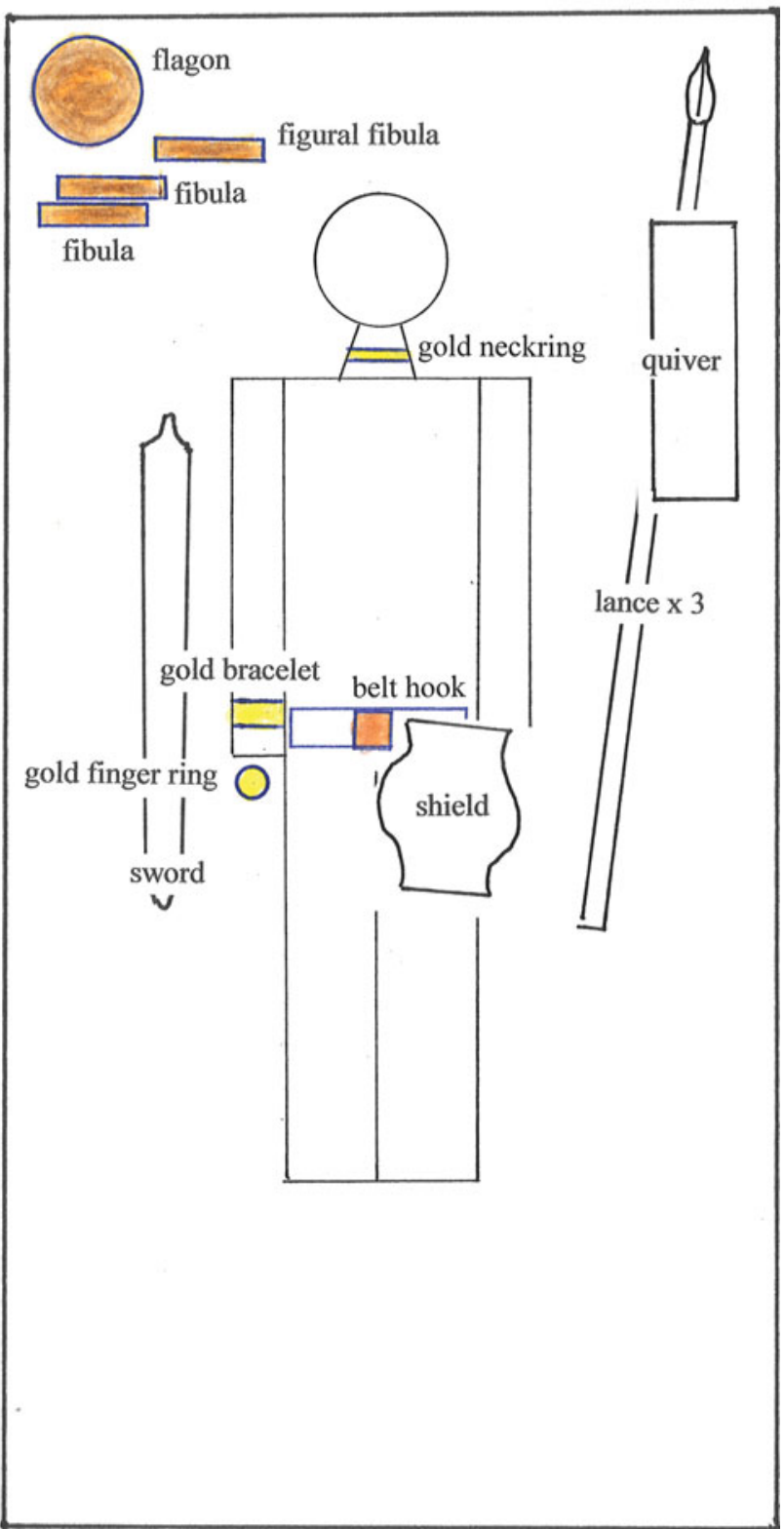

Figure 4. Plan of Glauberg grave 1, based on information in Herrmann (2002, 100, fig. 63). (Drawing: P.S. Wells.)

abundance of weapons in the grave. It is unlikely that he could have carried all of these weapons at the same time. The sword could have been attached to a belt, so that would not require a hand. The quiver could have been worn on his back. But holding the shield, three lances and the bow, at the same time that he was wearing a sword and a quiver, would have been extremely awkward, if not impossible. It is thus quite apparent that the weapon assemblage was to complete the visual display of an aspect of this man's 
role in his community, not to indicate how he was actually outfitted when he was called upon to fight. The high position of the sword, relative to the man's waist, suggests that it was not attached to a belt at the time of burial, but placed separately in the grave.

Thus we can understand the visual presentation of this grave in at least two ways. First, the assemblage included a number of different objects whose clearly visible features refer directly to other objects through the motifs (ambiguous creatures, human-like heads on the fibula and the belt hook) and through style (incised curvilinear patterning and texturing ornament on all three fibulae, belt hook, flagon, scabbard, bracelet and finger ring). Second, the way that the objects were laid out in the grave was a visual representation (a diagram) of the relationships between different spheres of activity in which the buried individual engaged with his community-person of elite social status (gold ornaments and highly decorated bronze objects), host (flagon) and warrior. The spatial arrangement of the objects draws attention to the fact that these three domains were represented separately, at the same time that they were united and framed together within the boundaries of the grave pit.

\section{Reinheim}

The grave at Reinheim in the Saarland of Germany was excavated in 1954 and published in 1965 (Keller 1965).

The objects: Very little skeletal material survived, but, on the basis of the grave goods, the burial is believed to be that of a woman. Like Glauberg 1, Reinheim contained a series of figurally ornamental complex objects-a gold neckring, gold bracelet, two bronze fibulae, a bronze jug and a bronze mirror. The two ends of the gold neckring are richly ornamented with human-like heads with palmettes above them, heads of birds of prey between the palmettes, complex texturing, a pair of bulbous knobs, and below the knobs faces that look like those of owls. The ornate gold bracelet also has a human-like face on each end, ornate texturing and owl-like faces underneath each of two knobs. The ornamentation on the neckring and on the bracelet is thus very similar, but not exactly the same. Other figural ornament in the grave includes two small human figure pendants, four faces on the gilded bronze jug, a bronze fibula with a human head on the foot end and a bronze fibula in the form of a rooster. As with Glauberg 1, the entire set of contents of the Reinheim grave can be understood as a bundle-all of the objects relate directly to one another, and together they form a meaningful set.

The grave space: As with Glauberg, the spatial arrangement of the objects in Reinheim can tell much about visual principles at this time (Fig. 5). The burial space here, framed by a wooden chamber measuring $3.5 \mathrm{~m}$ on a side, was left largely empty.

Within the space of the interior of the chamber, we can identify four separate sub-sets of objects. The body, which at Reinheim was almost completely disintegrated, was placed close to the centre of the chamber in a north-south orientation, with the head to the north. Personal ornaments, many of them visually complex, adorned the body: neckring, four bracelets, two gold finger rings, two gold and two bronze fibulae. These constitute one set of interrelated objects. The neckring and the gold bracelet match each other in decorative motifs, and the other personal ornaments constitute a coherent set such as occurs in many other graves of the period.

A second set consists of a series of small objects of different character placed east of the woman's head (Keller 1965, pl. 5, bottom). These include 131 amber beads, 18 glass beads, three jet beads, two perforated stones, a fossil, a piece of chalcedony, a piece of jasper, a piece of chert and a flint flake.

A third set consists of vessels associated with feasting, again similar to Glauberg 1 . But this time there are five vessels: the gilded bronze jug with figural ornament, two gold bands from drinking horns and two bronze bowls from Etruscan Italy.

Fourth, a bronze mirror was recovered about half a metre west of the body at the level of the neck.

Thus, in the Reinheim grave, we have four visually distinct groups of objects, carefully laid out during the funerary ceremony in separate parts of the chamber, each expressing a different, but interrelated, aspect of this person's relation to the community.

As with Glauberg, the objects were arranged in such a way as to emphasize different domains of the individual's social role in her community. The four groups are separated by open spaces. In the centre, the woman was outfitted with visually enchanting objects of gold, bronze and glass. Above her head to her left was placed a rich variety of beads and other objects indicating her status and her connections to other parts of Europe. Next to her left side, but separated from her body, was a set of vessels for hosting a feast. At the same distance to her right was a bronze mirror. As with Glauberg, but in a more spacious setting, all of these visually complex objects were enclosed by the frame of the chamber walls.

\section{Principles of visual order: Early La Tène (fifth-fourth centuries $\mathrm{BC}$ )}

The visually most fascinating (enchanting in Gell's terminology) objects of this period represent three aspects of the buried individuals' roles in their 


\section{Reinheim}

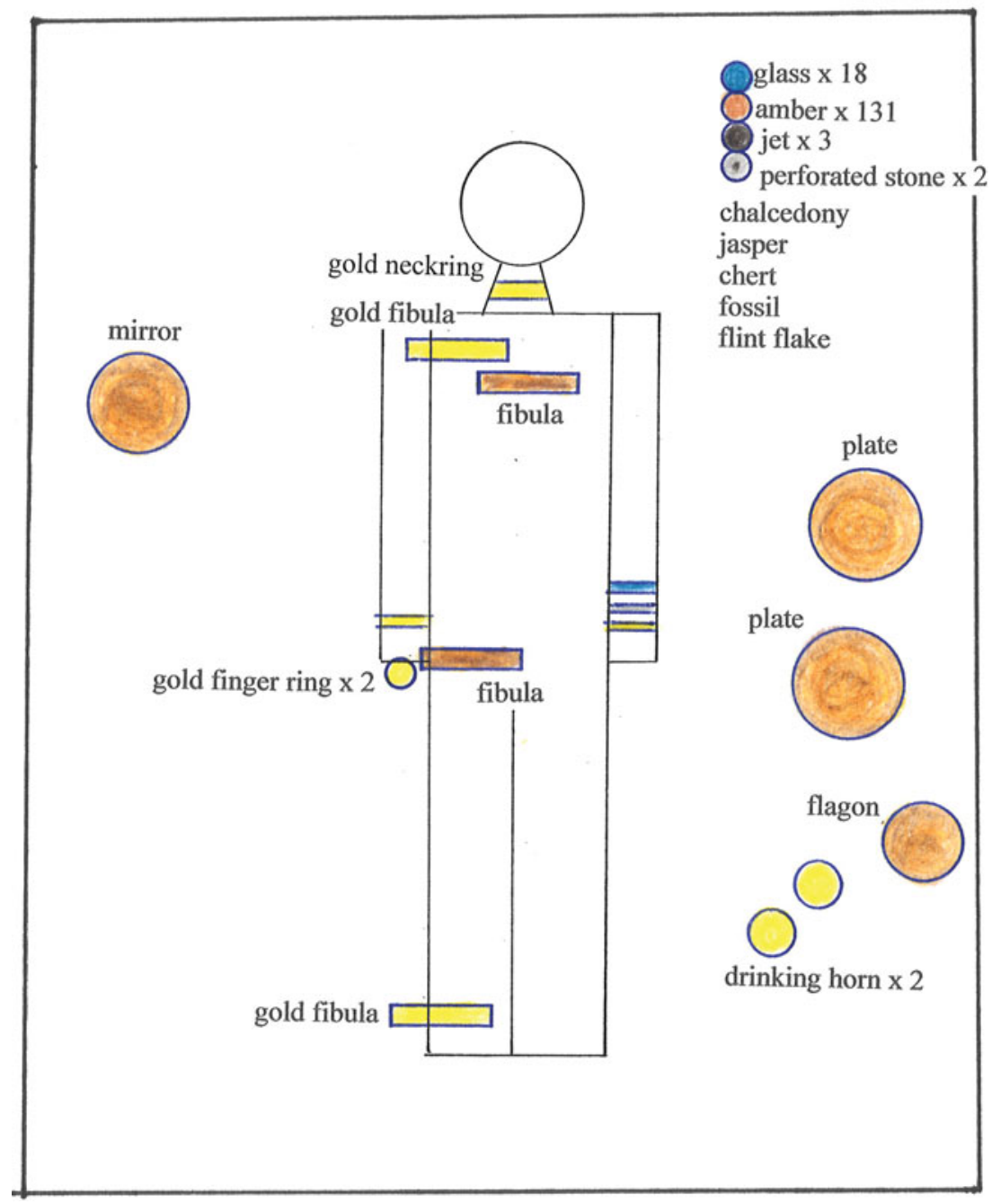

Figure 5. Plan of the grave at Reinheim, based on information in Keller (1965, 16, fig. 4). (Drawing: P.S. Wells.)

communities. These are: 1) personal ornamentsfibulae and ring jewellery in both the Glauberg and Reinheim burials, as well as the many small special objects in Reinheim; 2) bronze vessels associated with feasting; and 3) in the case of the man in Glauberg 1 , weaponry. In terms of the spatial arrangement of these enchanting objects, the ornaments are directly associated with the two individuals, the vessels are within the burial chambers but set aside from the bodies of the persons, and in Glauberg 1, the weaponry is also set aside of the man (except the shield, which was placed on his body). The key aspect of the visual order for this period, the style known as 'Early Celtic Art', is the direct personal association of the visually most complex and striking objects with the individuals with whom they were buried. (These patterns are also evident in many other graves of this period.)
Objects as agents: The idea that objects can act as agents-can make humans do things and think in particular ways-has been richly explored by archaeologists, as well as by scholars in other disciplines. Since there are many excellent studies of the issue, I shall not repeat the discussion (see, e.g., Bauer \& Kosiba 2016; Brown 2015; Dobres \& Robb 2000; Latour 2005; Malafouris 2013; Olsen 2010; Turkle 2007; Van Oyen 2016). The important point here is that the objects in the two graves, as they were placed in the burial spaces in the course of the funerary performance, caused the participants to think about the roles of the buried individuals in their communities and about the social relationships in which they were engaged.

Relational ontologies-objects and spaces: The meaning of objects is directly affected by their 
association with other objects (Van Oyen 2016; Watts 2013). The relationships between different objects create their meaning and their very essence, or ontology (Herva 2010:, 326, 335). For example, Tom Cummins $(2007,277-8)$ has shown that, in prehistoric South America, the significance of objects is very largely dependent upon their spatial relationships with other objects. María Zedeño (2008; 2009; 2013) has developed this point with reference to bundles of the Plains Indians (see also Lemonnier 2012,96; Skousen \& Buchanan 2015), and Murray and Mills (2013) have discussed the related character of caches in the southwest of the US. Angela Haas (2007) has shown that similar relationships exist between objects in wampum belts on the North American east coast, with the association of materials and contained objects creating specific meanings.

To this discussion about the relationships between associated objects, I add the importance of relationships between objects in space, an issue to which European archaeology can make a special contribution, as I suggest with the two graves I use as examples. In these two examples, the arrangements tell us about relationships between human bodies, visually complex personal ornaments, social objects related to feasting and the kinds of interactions represented by weapons. In both graves, the objects as things and the arrangements of them in the spaces of the graves are both essential to the overall visual order communicated by the graves as coherent bundles.

Thus the essence of objects - their ontologiesdepends upon the relationships between the different interrelated and associated objects, and also upon the relationships between the objects and the spaces in which they were used and in which they were deposited.

\section{Late second-early first centuries вс: Late La Tène}

Examining similar categories of material culture of the second and first centuries $\mathrm{BC}$ in the same region of Europe, we find profound differences that are related to differences in visual order and in socio-political dynamics. Visually complex objects such as those in Glauberg and Reinheim are much less numerous, and we do not find them often in graves. Instead, visually complex objects tend now to be large items that were ultimately deposited in special places out in the open, where their display could be seen by large numbers of people who participated in the ceremonies during which they were deposited. Among the most important such settings were bodies of water (Guichard 2012; Leins \& Farley 2015). Examples include the Battersea Shield, recovered in the River Thames (Joy 2015, 45, fig. 26) and the Gundestrup Cauldron, from a bog

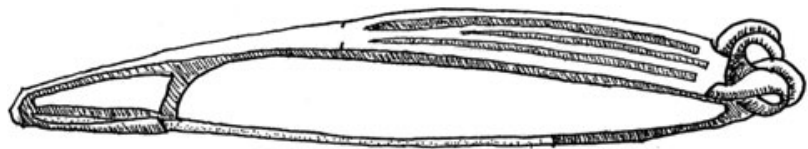

Figure 6. Typical Nauheim fibula, length about $8.5 \mathrm{~cm}$. (Drawing: J.C. Wells, based on Osborne 1881, pl. 3, 8.)

in northern Denmark (Hunter et al. 2015, 260-71, figs. 253-260).

Graves are relatively few in most parts of temperate Europe during this period; other means of disposing of human bodies were employed than subsurface burial (Hahn 2013). Where graves do exist, for example in the huge cemetery at Wederath in the Moselle valley (Haffner 1989), exceptionally richly outfitted graves are rare (Schönfelder 2002). Among the graves outfitted with more objects than most, such as Clemency in Luxembourg (Metzler et al. 1991); Badenheim in the Rhineland (Böhme-Schönberger 1998); Olewig 3 (Trier Augustusstadt 1984, 158-62) and Wincheringen in the Moselle valley (Trier $A u$ gustusstadt 1984, 299-307); Boireau in Corrèze, France (Dussot et al. 1992); and Welwyn, north of London (Stead 1967), no visually complex objects comparable to those in Glauberg and Reinheim were recovered. Personal ornaments such as fibulae and belt hooks are visually plain at this time. As plans of these graves indicate, they have less open space-affordance-than the rich graves of the earlier period.

For comparison with the visually complex objects of the earlier period, I examine here two categories of objects that are represented in both the earlier and the later contexts-fibulae and belt hooks-and then a new category-coins.

\section{Nauheim fibulae}

The Nauheim fibula is one of the most common forms of fibula in this period and it is found distributed widely over Europe (Maute 1994, 463, fig. 91). In marked contrast to the fibulae in Glauberg and Reinheim, Nauheim fibulae have flat bows, ornamented with at most simple linear patterns (Fig. 6). As Hans Drescher (1955) has shown, the design of the Nauheim fibula was created specifically so that the fibula could be manufactured through mass production. Such plain objects do not hold visual attention as more complex objects do (Gibson 1979). Thus the Nauheim fibula of this late period was intended to serve very different purposes from the complex figurally ornamented fibulae of Glauberg and Reinheim. Other types of fibula from this period are similarly plain (Gebhard 1991). 


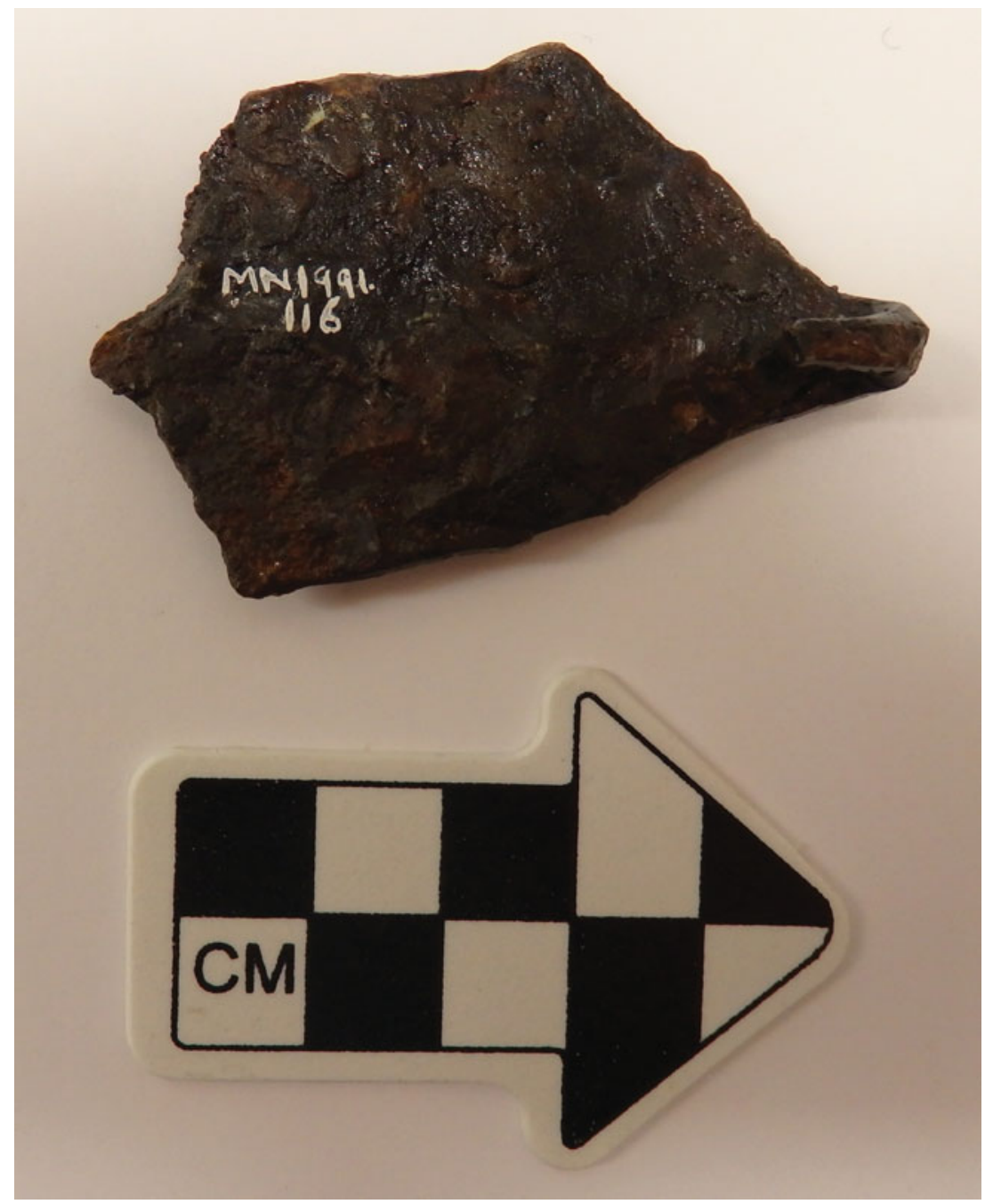

Figure 7. Belt hook from the oppidum at Kelheim, Lower Bavaria. Iron. Length $6.2 \mathrm{~cm}$. (Photograph: P.S. Wells.)

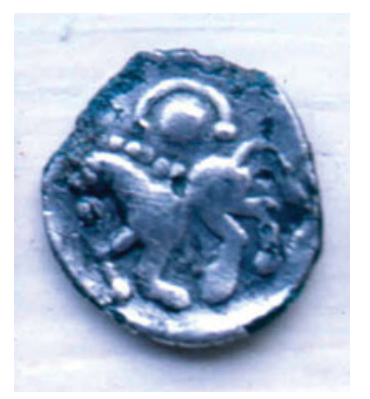

Figure 8. Coin from the oppidum at Kelheim, Lower Bavaria. Bronze with silver coating. Diameter $1.4 \mathrm{~cm}$. Note the representations of horse, rider and neckring. (Photograph: P.S. Wells.)

\section{Belt hooks}

Belt hooks of this period also tend to be very plain, without the rich complexity of the Glauberg example.
The belt hook in Figure 7 is from the Late La Tène oppidum settlement at Kelheim in Bavaria. It is a simple slab of forged iron with a small hook to serve its purpose. Similarly plain belt hooks were placed in some graves, for example Wederath Grave 332 (Haffner 1989, 53, fig. 33).

\section{Coins}

From around the middle of the second century вс, coins represent a common new phenomenon in the visual culture of the Iron Age (Fig. 8). The first coins were minted in temperate Europe around the start of the third century $\mathrm{BC}$, but they did not become abundant until after the middle of the second century вс, when coins in bronze, silver and gold came into circulation (Kellner 1990). Coins presented the first mass-produced complex objects and the first widely disseminated images in this part of the world. The ma- 
jority of coins have complex visual structures on them, as in the example in Figure 8, with a wide range of specific themes and patterns (Allen \& Nash 1980). Many have representations of human heads, many have horses, sometimes with riders, others have representations of objects, including amphorae, fibulae, neckrings and weapons. Many bear brief legends in Greek or Latin characters, usually a name of an individual or a group; they constitute the first widespread writing in temperate Europe (Allen \& Nash 1980, chapter 6).

\section{Principles of visual order: Late La Tène (second and final centuries вС)}

The principles of visual order in the final phase of the Iron Age were markedly different from those of Early La Tène. The visually most complex objects were not personal ornaments, nor were they deposited with individuals. Rather than being arranged on or around bodies in graves, they were displayed and deposited in wide open spaces, including flat fields (Snettisham), lakes (La Tène) and ponds (Gundestrup), rivers (Thames, Witham) and hilltops (the 'burned offering places' of the circumalpine regions). The agency of such objects related to whole communities, members of which could participate in the openair rituals, not just to individuals with whom they were buried.

The contexts in which they were deposited link these complex objects with landscape features, not with individual persons. The rituals through which such objects were deposited had the effect of binding the participating community members with the landscape in which the deposits were performed and the community lived.

\section{Visual order and social and political change}

The objects under discussion here can be linked to prevailing social and political conditions of their times, and they can contribute to a better understanding of those conditions. For the earlier period, much has been written about the social and political circumstances represented by the richly outfitted graves (Fürstengräber), with discussion about the most appropriate models to apply (Baitinger et al. 2012; Hunter \& Joy 2015, 59). Should the situation be modelled after those of medieval European principalities, ethnohistorically documented chiefdoms, or some other form of social and political organization (Zürn 1970, 118-28)? J.D. Hill (2006) has argued that, rather than thinking in terms of these 'triangular' social models, with a few individuals of highest status at the top and the mass of population at the bottom, we should consider the possibility of 'segmentary' so- cieties, without strict social hierarchies, but fluid, changing social structures. The 'classic' Fürstengräber such as Glauberg and Reinheim were part of a relatively short-lived phenomenon reflecting special social and political conditions from around 530 to about 380 вс. Settlement structures, burial practices and distribution of complex objects all make clear that conditions varied across temperate Europe, and they were in a constant state of flux.

It has been argued that, rather than signifying established high statuses, richly outfitted burials indicate periods of competition for status and power. The complex personal ornaments discussed above were designed specifically to attract visual attention (Gell 1998; Gibson 1979), and they would certainly be understandable in the context of competition for position and power.

In the latter half of the second and the first centuries $\mathrm{BC}$, the plainness of the objects in even the richest graves, the lack of sizeable open spaces (affordances) in graves and the general dearth of graves overall suggest major changes in social and political dynamics. In this latter period, portrayals by Caesar and other Roman writers have been interpreted to indicate the existence of 'kings' and other aspects of political organization among the Gauls in the middle of the final century вс (Kaenel 2012). But we must remind ourselves that Caesar was a general commanding armies fighting against the peoples of Gaul, not an anthropologist doing field research.

The character of the excavated oppida, which Caesar portrayed as great tribal capitals, does not suggest the existence of strong political leadership in the Late Iron Age communities (von Nicolai 2012). Despite extensive excavations, no central governmental buildings have been identified at the oppida, nor any other signs that they were political capitals. The tendency today is to view the oppida as essentially agglomerations of small 'village-like' communities, sharing the defensive advantage of the great walls and economic activities of manufacturing and trade, but not a coherent political structure. Recent research suggests that many individuals and families of elevated status lived at residences in the countryside away from the oppida (Büchsenschutz \& von Nicolai 2012). Manuel Fernández-Götz (2014) argues that the key aspect of the social system of this period was the extended family, rather than a hierarchical political structure, an idea that would be consistent with the emerging settlement evidence.

A glance through the catalogues of the recent major exhibits of European Iron Age 'art' (Beilharz et al. 2012; Farley \& Hunter 2015; Müller 2009) makes clear the contrast between highly complex and ornate per- 
sonal objects of the earlier period and the strikingly plain personal accoutrements of the later. In the earlier period, a great many objects were crafted with powerful visual features to attract and hold the viewer, and most of these were small and highly complex, to be worn by individuals (as in the Glauberg and Reinheim graves). In the later period, the same kinds of objects (fibulae, belt hooks, neckrings) were plain and without special visual properties. Instead, a small number of much larger, visually more complex objects were made that served to attract and hold attention for a different social and political purpose-for entire communities to see and experience.

The ontology of space in this later context was different from that of the earlier. Rather than being expressed in closed graves, the visual experiences surrounding the performances that involved objects such as the ornate shields and swords thrown into water and the cauldrons deposited in ponds took place in the open, especially in places in the landscape that afforded vast vistas. Open-air sites such as Gournay and Ribemont from a slightly earlier period (Brunaux 1996), the platforms built into Lake Neuchâtel at La Tène (Alt 2007), the Thames and Witham rivers and the Brandopferplätze of the Alpine regions (Zanier 1999) give us some idea of what the visual experiences associated with these objects were like. These experiences, that involved performances with large, highly visible and visually complex objects such as the Gundestrup Cauldron and the Battersea and Witham shields, would have fostered political solidarity among the much larger communities of people of the end of the Iron Age than the groups that participated in the burial rituals in the earlier period.

During the second century $\mathrm{BC}$, communities in temperate Europe expanded their interactions widely to other parts of Europe, to the Mediterranean world and even further afield into Asia. Economies became much larger and more complex at the oppidum centres, as evidenced by the mass production of pottery, iron and other materials, as well as the great expansion in the minting of coins. The scale of the economic, social and political changes is apparent in the masses of Roman transport amphorae and other goods recovered on sites of this period in Gaul and elsewhere in temperate Europe (discussion in Wells 2012, 196-221). For the organization of the production to generate trade goods for exchange for desired products from the Mediterranean world and beyond, a new kind of leadership had to emerge, and with it new objects of visual complexity. These were larger objects that could be employed in performances involving larger numbers of people in the political and religious rituals that encouraged the social solidarity needed for the economic changes that would enable the production of ever-increasing quantities of tradable goods, as well as the political solidarity to resist incursions by threatening neighbours to the south ('Romans') and north ('Germans'), at least for a time.

By the second century вс, communities of temperate Europe were entering into the rapidly expanding commercial networks of the greater Mediterranean world and wider Eurasia in what Christopher Ehret (2002) has called the 'Commercial Revolution' of the final millennium вс. The social and political dynamics of this period were on a much larger scale than those of the fifth and fourth centuries BC. The ways in which the visuality of crafted objects and of spaces were used had changed fundamentally.

\section{Conclusion: using changes in visual order as an approach to studying prehistoric complex societies worldwide}

By focusing our attention on the character of the visual order of one period of time and comparing it to that of another, we can to some extent experience the visual world as the people we are studying did and thereby gain some understanding of the social differences between the two times. In the earlier period examined above, visual complexity in objects was directly associated with individuals, and the limited space within burials organized to draw attention to the categories of experience that the performance of the funerary rituals was meant to emphasize. In the later period, when communities were much larger and interactions with other parts of the world much more highly developed, visual attention was no longer focused on individuals, but instead on communities.

From these examples in prehistoric Europe, I would argue that identifying principles of visual order in different contexts can contribute substantially to greater understanding of social and political change in many different cultural contexts. The kinds of objects on which craftworkers lavished their attention and skill, the contexts in which those objects were used and deposited and the spatial configurations of those objects with relation to one another and to other objects with which they were associated, can all provide insight into themes that are most important to a society.

For any study of visual order and its relation to social and political dynamics in other settings, I would emphasize two main questions: 1) What kinds of objects were crafted to be visually complex? Were they everyday objects used by the majority of people in a society, such as household implements and agricultural tools, or were they rare items used for 
display by elite members of communities? Were they objects associated with specific individuals, as evidenced by their placement in single graves or under the floors of houses? Or were they objects that a majority of members of a community would see regularly, such as statues or monumental structures in public places? 2) In what kinds of contexts were the objects used and deposited? Were they used in domestic settings, in small community gatherings, or in big urban spaces? Were they deposited with individuals in graves, or within ritual structures, or in natural locations such as caves and lakes? Key to this kind of analysis is the visual complexity of the objects and the ontology of the spaces in which they were used and deposited.

Applying this approach can lead to new insights into processes of social and political change in any cultural contexts, such as the emergence of urbanism in the Near East, the development of Shang civilization in east Asia, the formation of the Classic Maya in Mesoamerica and the expansion of the Inca Empire in South America, to name just a few examples.

\section{Acknowledgements}

I thank John Robb for inviting me to participate in the highly stimulating forum at the SAA meetings in Orlando in 2016 from which this paper derives. I thank Thomas LessigWeller of Keltenwelt am Glauberg for the photographs, Figures 2 and 3, and for permission to use them here. And I thank John Robb and the two anonymous reviewers for their comments that enabled me to improve the paper.

\section{Peter S. Wells Department of Anthropology University of Minnesota Twin Cities Minneapolis, MN 55455 \\ USA \\ Email:wells001@umn.edu}

\section{References}

Allen, D.F. \& D. Nash, 1980. The Coins of the Ancient Celts. Edinburgh: Edinburgh University Press.

Alt, K.W., 2007. La Tène: Die Untersuchung, die Fragen, die Antworten. Biel: Museum Schwab.

Baitinger, H., L. Hansen \& C. Pare, 2012. Ein Zentrum an der Peripherie? Der Fürstensitz auf dem Glauberg, in Die Welt der Kelten, Zentren der Macht - Kostbarkeiten der Kunst, eds. D. Beilharz, T. Hoppe, D. Krausse, F. Müller \& C. von Nicolai. Ostfildern: Thorbecke, 157-64.

Baitinger, H. \& B. Pinsker (eds.), 2002. Das Rätsel der Kelten vom Glauberg. Stuttgart: Theiss.
Bauer, A.M. \& S. Kosiba, 2016. How things act: an archaeology of materials in political life. Journal of Social Archaeology 16(2), 115-41.

Beilharz, D., T. Hoppe, D. Krausse, F. Müller \& C. von Nicolai (eds.), 2012. Die Welt der Kelten, Zentren der MachtKostbarkeiten der Kunst. Ostfildern: Thorbecke.

Berman, M., 1981. The Reenchantment of the World. Ithaca (NY): Cornell University Press.

Böhme-Schönberger, A., 1998. Das Grab eines vornehmen Kriegers der Spätlatènezeit aus Badenheim: Neue Forschungen $\mathrm{zu}$ den Schwertscheiden mit opus interrasile-Zierblechen. Germania 76, 219-56.

Brown, B., 2015. Other Things. Chicago (IL): University of Chicago Press.

Brück, J., 1999. Ritual and rationality: some problems of interpretation in European archaeology. Journal of European Archaeology 2, 313-44.

Brunaux, J.-L., 1996. Les religions gauloises: rituels celtiques de la Gaule indépendante. Paris: Editions Errance.

Buchanan, M.E. \& B.J. Skousen (eds.), 2015. Tracing the Relational: The archaeology of worlds, spirits, and temporalities. Salt Lake City (UT): University of Utah Press.

Büchsenschutz, O. \& C. von Nicolai, 2012. Gut geschützt im Viereck: Leben auf dem Lande in spätkeltischer Zeit, in Die Welt der Kelten, Zentren der Macht - Kostbarkeiten der Kunst, eds. D. Beilharz, T. Hoppe, D. Krausse, F. Müller \& C. von Nicolai. Ostfildern: Thorbecke, 382-7.

Cummins, T., 2007. Queros, aquillas, uncus, and chulpas: the composition of Inka artistic expression and power, in Variations in the Expression of Inka Power, eds. R.L. Burger, C. Morris, R. Matos Mendieta, J. Pillsbury \& J. Quilter. Cambridge (MA): Harvard University Press, 267-311.

De Bolla, P., 2003. The Education of the Eye: Painting, landscape, and architecture in eighteenth-century Britain. Stanford (CA): Stanford University Press.

Dobres, M.-A. \& J.E. Robb, 2000. Agency in Archaeology. New York (NY): Routledge.

Drescher, H., 1955. Die Herstellung von Fibelspiralen. Germania 33, 340-49.

Dussot, D., G. Lintz \& D. Vuaillat, 1992. La sépulture gauloise de Boiroux commune de Saint Augustin (Corrèze). Aquitania 10, 5-30.

Ehret, C., 2002. The Civilization of Africa: A history to 1800. Charlottesville (VA): University of Virginia Press.

Farley, J. \& F. Hunter, eds., 2015. Celts: Art and identity. London: British Museum Press.

Fernández-Götz, M., 2014. Identity and Power: The transformation of Iron Age societies in northeast Gaul. Amsterdam: Amsterdam University Press.

Forge, A., 1970. Learning to see in New Guinea, in Socialization: The approach from social anthropology, ed. P. Mayer. London: Tavistock, 269-91.

Frey, O.-H. \& F.-R. Herrmann, 1997. Ein frühkeltischer Fürstengrabhügel am Glauberg im Wetteraukreis, Hessen. Bericht über die Forschungen 1994-1996. Germania 75(2), 459-550. 
Gebhard, R., 1991. Die Fibeln aus dem Oppidum von Manching. Stuttgart: Franz Steiner.

Gell, A., 1992. The technology of enchantment and the enchantment of technology, in Anthropology, Art and Aesthetics, eds. J. Coote \& A. Shelton. Oxford: Clarendon Press, 40-63.

Gell, A., 1998. Art and Agency: An anthropological theory. Oxford: Clarendon Press.

Gibson, J.J., 1977. The theory of affordances, in Perceiving, Acting, and Knowing: Toward an ecological psychology, eds. R. Shaw \& J. Brandsford. Hillsdale (NJ): Lawrence Erlbaum Associates, 67-82.

Gibson, J.J., 1979. The Ecological Approach to Visual Perception. Hillsdale (NJ): Lawrence Erlbaum Associates.

Gilchrist, R., 2012. Medieval Life: Archaeology and the life course. Woodbridge: Boydell Press.

Goldhill, S., 1996. Refracting classical vision: changing cultures of viewing, in Vision in Context, eds. T. Brennan \& M. Jay. New York (NY): Routledge, 15-28.

Gregory, R.L., 1998. Eye and Brain: The psychology of seeing (5th edition). Oxford: Oxford University Press.

Groleau, A.B., 2009. Special finds: locating animism in the archaeological record. Cambridge Archaeological Journal 19(3), 398-406.

Guichard, V., 2012. Spiegel einer Gesellschaft im Wandel: Die spätkeltische Kunst, in Die Welt der Kelten, Zentren der Macht - Kostbarkeiten der Kunst, eds. D. Beilharz, T. Hoppe, D. Krausse, F. Müller \& C. von Nicolai. Ostfildern: Thorbecke, 400-409.

Haas, A.M., 2007. Wampum as hypertext: an American Indian intellectual tradition of multimedia theory and practice. Studies in American Indian Literatures 19(4), 77-100.

Haffner, A., 1989. Gräber - Spiegel des Lebens: Zum Totenbrauchtum der Kelten und Römer am Beispiel des TrevererGräberfeldes Wederath-Belginum. Mainz: Philipp von Zabern.

Hahn, E., 2013. Die menschlichen Skelettreste, in Ergebnisse der Ausgrabungen in Manching-Altenfeld 19661999, eds. S. Sievers, M. Leicht \& B. Ziegaus. Wiesbaden: Reichart, 669-704.

Helms, M.W., 2012. Nourishing a structured world with living metal in Bronze Age Europe. World Art 2(1), 10518.

Herrmann, F.-R., 2002. Der Glauberg: Fürstensitz, Fürstengräber und Heiligtum, in Das Rätsel der Kelten vom Glauberg, eds. H. Baitinger \& B. Pinsker. Stuttgart: Theiss, 90-107.

Herva, V.-P., 2010. Maps and magic in Renaissance Europe. Journal of Material Culture 15(3), 323-43.

Hill, J.D., 2006. Are we any closer to understanding how later Iron Age societies worked (or did not work)? in Les mutations de la fin de l'age du Fer, ed. C. Haselgrove. Glux-en- Glenne: Collection Bibracte, 169-79.

Hunter, F., M. Goldberg, J. Farley \& I. Leins, 2015. Celtic arts in the long term: continuity, change and connections, in Celts: Art and identity, eds. J. Farley \& F. Hunter. London: British Museum Press, 261-71.
Hunter, F. \& J. Joy, 2015. A connected Europe, c. 500-150 BC, in Celts: Art and identity, eds. J. Farley \& F. Hunter. London: British Museum Press, 53-79.

Ingold, T., 2012. Toward an ecology of materials. Annual Review of Anthropology 41, 427-42.

Jacobsthal, P., 1944. Early Celtic Art. Oxford: Clarendon Press.

Jones, G., 1984. A History of the Vikings. Oxford: Oxford University Press.

Joy, J., 2015. Approaching Celtic art, in Celts: Art and identity, eds. J. Farley \& F. Hunter. London: British Museum Press, 36-51.

Kaenel, G., 2012. Komplex und vielfältig: Die spätkeltische Gesellschaft, in Die Welt der Kelten, Zentren der Macht - Kostbarkeiten der Kunst, eds. D. Beilharz, T. Hoppe, D. Krausse, F. Müller \& C. von Nicolai. Ostfildern: Thorbecke, 388-95.

Keller, J., 1965. Das keltische Fürstengrab von Reinheim. Mainz: Römisch-Germanisches Zentralmuseum.

Kellner, H.-J., 1990. Die Münzfunde von Manching und die keltischen Fundmünzen aus Südbayern. Stuttgart: Franz Steiner.

Knight, V.J. Jr., 2013. Iconographic Method in New World Prehistory. Cambridge: Cambridge University Press.

Kopytoff, I., 1986. The cultural biography of things: commoditization as a process, in The Social Life of Things: Commodities in cultural perspective, ed. A. Appadurai. Cambridge: Cambridge University Press, 64-91.

Latour, B., 2005. Reassembling the Social: An introduction to actor-network-theory. Oxford: Oxford University Press.

Leins, I. \& J. Farley, 2015. A changing world, c. 150 BC-AD 50, in Celts: Art and identity, eds. J. Farley \& F. Hunter. London: British Museum Press, 109-27.

Lemonnier, P., 2012. Mundane Objects: Materiality and nonverbal communication. Walnut Creek (CA): Left Coast Press.

Livingstone, M., 2002. Vision and Art: The biology of seeing. New York (NY): Harry N. Abrams.

Lowenthal, D., 1985. The Past is a Foreign Country. Cambridge: Cambridge University Press.

Macfarlane, R., 2015. Landmarks. London: Hamish Hamilton.

Malafouris, L., 2013. How Things Shape the Mind: A theory of material engagement. Cambridge (MA): MIT Press.

Maute, M., 1994. Fibel und Fibeltracht: Latènezeit: Quellen, in Reallexikon der germanischen Altertumskunde vol. 8, 458-67. Berlin/New York: Walter de Gruyter.

Megaw, R. \& V. Megaw, 2001. Celtic Art. London: Thames \& Hudson.

Metzler, J., R. Waringo, R. Bis \& N. Metzler-Zens, 1991. Clemency et les tombes de l'aristocratie en Gaule belgique. Luxembourg: Musée National d'Histoire et d'Art.

Müller, F. (ed.), 2009. Art of the Celts 700 BC to AD 700. Bern: Historisches Museum.

Murray, W.F. \& B.J. Mills, 2013. Identity communities and memory practices: relational logics in the US 
Southwest, in Relational Ontologies: Humans, animals, things, ed. C. Watts. London: Routledge, 135-53.

Olsen, B., 2010. In Defense of Things: Archaeology and the ontology of objects. New York (NY): Altamira Press.

Osborne, W., 1881. Zur Beurtheilung des prähistorischen Fundes auf dem Hradischt bei Stradonic in Böhmen. Mitteilungen der Anthropologischen Gesellschaft in Wien 10, 234-60.

Schönfelder, M., 2002. Das spätlatènezeitliche Wagengrab von Boé (Dép. Lot-et-Garonne). Studien zu Wagen und Wagengräbern der jüngeren Latènezeit. (Monograph RGZM 54.) Mainz: Römisch-Germanisches Zentralmuseum.

Shapiro, M. 1963. Style, in Anthropology Today: Selections, ed. S. Tax. Chicago (IL): University of Chicago Press, 278303.

Skousen, B.J. \& M.E. Buchanan, 2015. Advancing an archaeology of movements and relationships, in Tracing the Relational: The archaeology of worlds, spirits, and temporalities, eds. M.E. Buchanan \& B. J. Skousen. Salt Lake City (UT): University of Utah Press, 1-17.

Stead, I.M., 1967. A La Tène III burial at Welwyn Garden City. Archaeologia 101, 1-62.

Trier Augustusstadt der Treverer, 1984. Mainz: Philipp von Zabern.

Turkle, S., 2007. Evocative Objects: Things we think with. Cambridge (MA): MIT Press.

Van Oyen, A., 2016. Historicising material agency: from relations to relational constellations. Journal of Archaeological Method and Theory 23, 354-78.

von Nicolai, C., 2012. Die keltische Version der antiken Stadt: Die Oppida, in Die Welt der Kelten, Zentren der Macht - Kostbarkeiten der Kunst, eds. D. Beilharz, T. Hoppe, D. Krausse, F. Müller \& C. von Nicolai. Ostfildern: Thorbecke, 357-71.

Watts, C. (ed.), 2013. Relational Ontologies: Humans, animals, things. London: Routledge.

Weber, M., 1919. Wissenschaft als Beruf. Munich: Duncker \& Humblot.

Weismantel, M., 2013. Inhuman eyes: looking at Chavín de Huantar, in Relational Ontologies: Humans, animals, things, ed. C. Watts. London: Routledge, 21-41.

Wells, P.S., 1996. Location, organization, and specialization of craft production in late prehistoric central Europe, in Craft Specialization and Social Evolution, ed. B. Wailes. Philadelphia (PA): University Museum, University of Pennsylvania, 85-98.
Wells, P.S., 2008. Image and Response in Early Europe. London: Duckworth.

Wells, P.S., 2012. How Ancient Europeans Saw the World: Vision, patterns, and the shaping of the mind in prehistoric times. Princeton (NJ): Princeton University Press.

Wilson, S., 2000. The Magical Universe: Everyday ritual and magic in pre-modern Europe. London: Hambledon \& London.

Wilson, T.D., 2002. Strangers to Ourselves: Discovering the adaptive unconscious. Cambridge (MA): Harvard University Press.

Zanier, W., 1999. Der spätlatènezeitliche- und römerzeitliche Brandopferplatz im Forggensee (Gde. Schwangau). Munich: C.H. Beck.

Zedeño, M.N., 2008. Bundled worlds: the roles and interactions of complex objects from the North American Plains. Journal of Archaeological Method and Theory 15, 362-78.

Zedeño, N.M., 2009. Animating by association: index objects and relational taxonomies. Cambridge Archaeological Journal 19(3), 407-17.

Zedeño, M.N., 2013. Methodological and analytical challenges in relational archaeologies: a view from the hunting ground, in Relational Ontologies: Humans, animals, things, ed. C. Watts. London: Routledge, 117-34.

Zürn, H., 1970. Hallstattforschungen in Nordwürttemberg. Stuttgart: Müller \& Gräf.

\section{Author biography}

Peter S. Wells specializes in late prehistoric, provincial Roman and early medieval European archaeology. Among his thematic interests are visual representation and perception, material aspects of ritual practice, and contact and interaction. His publications include The Barbarians Speak: How the Conquered Peoples Shaped Roman Europe (1999), Barbarians to Angels: The Dark Ages Reconsidered (2008), Image and Response in Early Europe (2008), and How Ancient Europeans Saw the World: Vision, Patterns, and the Shaping of the Mind in Prehistoric Times (2012). He is a Professor in the Department of Anthropology at the University of Minnesota. 